\title{
IPTEKS SISTEM PERSEDIAAN DALAM PENENTUAN HARGA POKOK PENJUALAN BAGI USAHA KECIL MENENGAH DI KECAMATAN MALALAYANG I BARAT KOTA MANADO
}

\author{
David Paul Elia Saerang ${ }^{1}$, Winston Pontoh ${ }^{2}$ \\ ${ }^{1}$ Program Studi Pendidikan Profesi Akuntansi, Fakultas Ekonomi dan Bisnis, Universitas Sam Ratulangi, Jl. \\ Kampus Bahu, Manado, 95115, Indonesia \\ E-mail : d_saerang@unsrat.ac.id
}

\begin{abstract}
Inventory is a component which reported in financial statement and gives an information about inventory circumstances of a company. Inventory also is a component that absorbs a lot of business capital, so that the security of the inventory must be maintained by a business unit, because the damage / loss of inventory means the lost capital (loss) of the business. The village of Malalayang I in Manado City is one of the regions known as a business-intensive region and also as part of an autonomous region to be specifically observed given that government bureaucracy and public services are considered to have the ability to implement good governance. The implementation of science and technology on inventory management has been carried out and has succeeded in achieving the goal of understanding small entrepreneurs in managing merchandise inventory in the form of applying inventory systems and determining cost of goods sold. Lack of understanding from small entrepreneurs about accounting, especially effective inventory management.
\end{abstract}

Keywords : inventory system, cost of goods sold, small medium enterprise

\section{PENDAHULUAN}

Persediaan merupakan salah satu komponen dalam laporan keuangan yang menggambarkan situasi sesungguhnya atas barang dagang yang ada di dalam sebuah unit usaha. Persediaan adalah sebuah komponen yang banyak menyerap modal usaha, sehingga keamanan atas persediaan tersebut harus dijaga oleh sebuah unit usaha, karena rusak/hilangnya persediaan berarti merupakan modal yang hilang (kerugian) dari usaha tersebut. Persediaan memiliki beberapa jenis metode penilaian, dan yang paling umum dikenal adalah FIFO, LIFO dan Rata-rata. Metode-metode penilaian ini pada akhirnya akan menentukan berapa besar nilai persediaan yang akan dilaporkan dalam laporan keuangan khususnya neraca dan berapa nilai harga pokok yang terealisasi (terjual) yang akan dilaporkan dalam laporan keuangan khususnya laporan rugi laba. Oleh sebab itu pemahaman yang baik atas metode penilaian yang akan berdampak pada penilaian harga pokok harus memiliki sistem yang baik agar memberikan informasi yang akurat dalam proses pengambilan keputusan sebuah unit usaha.

Kelurahan Malalayang Satu Kecamatan Malalayang Kota Manado merupakan salah satu wilayah yang dikenal sebagai wilayah padat bisnis dan juga sebagai bagian dari daerah otonomi untuk diamati secara khusus mengingat secara birokrasi pemerintahan dan pelayanan publik termasuk daerah yang dianggap memiliki kemampuan dalam menerapkan "good governance". Pemerintah daerah telah menerapkan berbagai praktek pemerintahan seperti antara lain: kebijakan dan pelayanan publik menyangkut administrasi, perijinan usaha/ lainnya, kesehatan, pendidikan, dan proses lelang proyek pembangunan fisik.

Namun demikian walaupun kemajuan dalam bidang pelayanan publik semakin baik, tetapi sebagaimana daerah lainnya, Kota Manado juga memiliki sebagian masyarakat yang perlu ditingkatkan akan pemahaman atas proses manajerial sederhana seperti sistem 
persediaan, guna meningkatkan perkembangan sebuah unit usaha, mengingat secara umum, distribusi pendapatan masyarakat Kota Manado masih perlu dikembangkan ke arah yang lebih merata yang idealnya tentu diharapkan dari upaya peningkatan kesejahteraan kelompok masyarakat marginal. Kelurahan Malalayang Satu Kecamatan Malalayang Kota Manado merupakan salah satu kelurahan yang berlokasi di wilayah Kota Manado dimana usaha kecil di dalamnya sudah merupakan sebuah unit usaha yang kompleks dari segi persediaan barang dagang. Struktur masyarakat yang kompleks turut mencerminkan struktur perekonomian yang tercipta di wilayah tersebut, baik dari segi usaha kecil, usaha menengah maupun usaha yang tergolong dalam skala besar. Adanya alih pengetahuan atas sistem persediaan dan penentuan harga pokok bagi kelompok masyarakat yang tergabung dalam kelompok usaha kecil diharapkan akan membuat masyarakat yang termasuk dalam kelompok usaha kecil akan lebih menyadari pentingnya aspek manajerial bagi masyarakat itu sendiri.Universitas Sam Ratulangi, khususnya Fakultas Ekonomi dan Bisnis merasa pentingnya melakukan penyuluhan dan sekaligus diskusi serta bagi pendapat dengan para pelaku usaha yang termasuk dalam jenis usaha kecil yang ada. Hal ini adalah sesuai dengan Tri Dharma Perguruan Tinggi yang salah satu unsurnya adalah pengabdian pada masyarakat. Dengan adanya latar belakang diatas maka permasalahan dari mitra adalah bagaimana sistem persediaan barang dagang dan penentuan harga pokok penjualan bagi usaha Kecil di Kelurahan Malalayang Satu Kecamatan Malalayang Kota Manado untuk pengembangan usaha mitra itu sendiri.

\section{TINJAUAN PUSTAKA}

Menurut Atrill dan McLaney (2006), Warren et al. (2009), Horngren et al. (2012), Kieso, et al. (2013), dan SAK No. 14, bahwa persediaan (inventories) merupakan aset yang diperoleh perusahaan dengan maksud untuk dijual kembali. Libby et al. (2011), dan Kinney dan Raiborn (2011) menambahkan bahwa, persediaan juga dapat dimaksudkan untuk memproduksi produk dan kemudian dijual kembali oleh perusahaan. Brigham dan Houston (2009) menjelaskan bahwa, persediaan merupakan komponen aset yang sangat penting dalam menciptakan laba bagi perusahaan lewat perputaran penjualannya.

Menurut Horngren et al. (2012), dan Kieso, et al. (2013) bahwa pembebanan biaya dari persediaan menjadi harga pokok penjualan atau disebut arus biaya akan dilakukan berdasarkan 2 (dua) sistem, yaitu sistem perpetual dan sistem periodik. Libby et al. (2011), Horngren et al. (2012), dan Kieso, et al. (2013) menjelaskan bahwa sistem perpetual merupakan sistem yang secara tepat waktu melakukan penelusuran atas perubahan akun persediaan dalam perusahaan, sedangkan sistem periodik merupakan sistem penelusuran biaya atas persediaan yang dilakukan oleh perusahaan secara periodik. Menurut Nikolai et al. (2010) Libby et al. (2011)Kimmel et al. (2011) Horngren et al. (2012)Kieso, et al. (2013) terdapat 4 (empat) metode dalam penentuan harga pokok penjualan yang berasal dari persediaan, yaitu : identifikasi khusus, metode rata-rata, metode masuk pertama keluar pertama, dan metode masuk terakhir keluar pertama.

\section{METODE DAN TEKNIK PENERAPAN IPTEKS}

\subsection{Metode Penerapan Ipteks}

Penerapan ipteks ditempuh dengan cara pelatihan dengan pendekatan metode studi

kasus yang langsung diaplikasikan pada teknis penerapan sistem persediaan hingga penentuan harga pokok penjualan.

\subsection{Teknik Penerapan Ipteks}

Teknik penerapan ipteks akan ditempuh melalui penjelasan metode pembebanan biaya yang menitikberatkan pada penentuan harga pokok lewat metode yang terdiri dari : (1) 
metode Masuk Pertama Keluar Pertama - MPKP (First In First Out - FIFO); dan (2) metode Masuk Terakhir Keluar Pertama - MTKP (Last In First Out - LIFO).

\section{PEMBAHASAN}

\subsection{Gambaran Objek Penerapan Ipteks}

Data tentang Kelurahan Malalayang Satu Kecamatan Malalayang Kota Manado adalah sebagai berikut :

Terbentuk Tahun 1901 (Bantik = Malalayang-Minanga)

Luas Wilayah : $900 \mathrm{Ha}$ (29.8 \% Luas Kec. Malalayang)

Batas Wilayah

Sebelah Utara : Pantai (Teluk Manado )

Sebelah Selatan : Desa Sea (Kab. Minahasa)

Sebelah Barat : Kel. Malalayang Satu Barat

Sebelah Timur : Kel. Malalayang Satu Timur

Tipologi Kelurahan : Jasa \& Perdagangan

Keunikan :

1. Memiliki dua wilayah berbeda ; pesisir pantai dan lereng perbukitan.

2. Menjadi pusat budaya Anak Suku Bantik Minanga.

Keunggulan :

1. Pelestarian Budaya Bantik ; Situs Budaya, Ritual Adat (Upasa), Tarian Adat (Mahamba), Pemecahan Rekor Muri.

2. Menjadi Pusat Pemerintahan,Pendidikan dan Kepolisian Kecamatan.

3. Memiliki Tempat Pengelolaan Air Bersih.

4. Memiliki Pengolahan Sampah Daur Ulang.

5. Pemanfaatan Lahan Tidur.

6. Satu Gerakan.

7. Orang Tua Asuh.

8. Partisipasi Masyarakat Dalam Pembangunan.

Mitra kegiatan yang turut serta adalah merupakan kelompok usaha mikro/kecil yang berjumlah 25 usaha kecil dan 25 orang pekerja bebas, dimana permasalahan mitra terletak pada pengelolaan persediaan barang dagang. Indikator keberhasilan atas kegiatan yang dilaksanakan adalah adanya pemahaman pengusaha kecil dalam kemampuan menerapkan pengelolaan persediaan barang dagang. Hal ini didukung dengan adanya pelatihan untuk menerapkan sistem persediaan dan harga pokok persediaan untuk pengelolaan administrasi usaha dan mendukung kegiatan analisis sederhana bagi kebutuhan informasi manajerial.

\subsection{Pembahasan}

Pemilik usaha menerapkan strategi harga untuk bersaing dengan usaha-usaha lainnya, terlebih dalam wilayah dan bidang usaha yang sama, yang melayani konsumen yang berdomisili untuk wilayah Kelurahan Malalayang. Sampai saat ini konsumen tidak hanya terbatas dilingkungan sekitar tempat usaha tapi juga dari temapat yang cukup jauh. Hal ini dimungkinkan karena wilayah Malalayang merupakan lokasi yang padat dan strategis, sehingga konsumen dapat berasal darimana saja, terlebih daerah Malalayang merupakan salah satu wilayah yang merupakan jalur transit wilayah Sulawesi, sehingga peluang usaha di wilayah ini dirasakan cukup besar. Strategi penjualan barang dagangan yang dilakukan oleh pemilik usaha membuahkan hasil yang baik, dengan menyediakan segala macam keperluan membuat konsumen merasa puas untuk berbelanja di tempat usaha ini.

Dalam perkembangan usaha ini terdapat banyak kebutuhan yang tentunya perlu penanganan yang baik dan perlu pengalaman terutama dalam hal pengelolaan modal kerja 
yang terbatas, sehingga dalam melakukan pengelolaan usaha, pemilik usaha menggunakan pengalaman yang dimiliki agar supaya dengan modal yang agak terbatas mampu memenuhi semua kebutuhan konsumen dalam waktu yang tepat. Seiring dengan jalannya operasional usaha, maka perencanaan dalam perpajakan perlu dilakukan agar kewajiban pajak perorangan pemilik dapat dilaksanakan dengan tepat, sehingga tidak terjadi kesalahan terutama pembayaran perpajakan yang berlebihan yang tidak sesuai dengan peraturan yang ada.

Kebutuhan yang saat ini dibutuhkan oleh usaha ini adalah sebuah pemahaman dan pengetahuan tentang penerapan sistem persediaan yang kemudian akan menentukan harga pokok penjualan. Pokok permasalahannya adalah kurangnya pengetahuan pemilik tentang pemahaman akuntansi, khususnya yang terkait dengan penerapan sistem persediaan dan penghitungan harga pokok penjualan yang merupakan salah satu bentuk pengelolaan barang modal. Hal yang paling sering terjadi adalah kesalahan dalam melakukan perhitungan sehingga sering terjadi penentuan harga jual yang tidak kompetitif. Penanganan permasalahan usaha kecil menengah dalam melakukan pengelolaan persediaan barang dagang dapat menerapkan metode persediaan Masuk Pertama Keluar Pertama (MPKP) dengan contoh tabel penghitungan sebagai berikut :

\begin{tabular}{|c|c|c|c|c|c|c|c|c|c|}
\hline \multirow{2}{*}{ Ket } & \multicolumn{3}{|c|}{ Masuk } & \multicolumn{3}{|c|}{ Keluar } & \multicolumn{3}{|c|}{ Saldo } \\
\hline & Unit & Harga/Unit & Total & Unit & Harga/Unit & Total & Unit & Harga/Unit & Total \\
\hline Saldo awal & 56 & 100 & 5,600 & & & & 56 & 100 & 5,600 \\
\hline \multirow[t]{2}{*}{ Pembelian } & 100 & 110 & 11,000 & & & & 56 & 100 & 5,600 \\
\hline & & & & & & & 100 & 110 & 11,000 \\
\hline Jual & & & & 56 & 100 & 5,600 & - & - & - \\
\hline Jual & & & & 4 & 110 & 440 & 96 & 110 & 10,560 \\
\hline Retur pembelian & & & & 10 & 110 & 1100 & 86 & 110 & 9,460 \\
\hline \multirow[t]{2}{*}{ Pembelian } & 50 & 200 & 10,000 & & & & 86 & 110 & 9,460 \\
\hline & & & & & & & 50 & 200 & 10,000 \\
\hline Jual & & & & 86 & 110 & 9,460 & & & \\
\hline Jual & & & & 14 & 200 & 2,800 & 36 & 200 & 7,200 \\
\hline \multirow[t]{2}{*}{ Retur penjualan } & 6 & 110 & 660 & & & & 6 & 110 & 660 \\
\hline & 14 & 200 & 2,800 & & & & 50 & 200 & 10,000 \\
\hline
\end{tabular}

\section{KESIMPULAN DAN SARAN}

\subsection{Kesimpulan}

Penerapan ipteks tentang pengelolaan persediaan telah dilaksanakan dan berhasil mencapai sasaran berupa adanya pemahaman pengusaha kecil atas pengelolaan persediaan barang dagang berupa penerapan sistem persediaan dan penentuan harga pokok penjualan. Kurangnya pemahaman dari para pengusaha kecil tentang akuntansi khususnya pengelolaan persediaan secara efektif.

\subsection{Saran}

Perlu memperhatikan target kelompok masyarakat untuk penerapan ipteks sesuai dengan bidang ilmu setiap institusi, hal ini disebabkan karena adanya bidang ilmu yang mungkin tidak aplikatif bagi sebuah target kelompok masyarakat tersebut. Diharapkan adanya keberlanjutan kegiatan yang serupa dengan materi lanjutan di kelompok masyarakat yang sama, agar terbentuknya kelompok binaan masyarakat usaha kecil yang mapan dalam penerapan ilmu pengetahuan dalam menyelesaikan masalah yang dihadapi sehari - hari, khususnya dalam bidang administrasi dan manajerial yang bertujuan untuk mengembangkan usaha kecil kelompok masyarakat tersebut.

\section{DAFTAR PUSTAKA}

Alexander, D., \& Nobes, C. (2010). Financial Accounting : An International Introduction, $4^{\text {th }}$ Edition. England : Pearson Education Limited. 
Atrill, P., \& McLaney, E. (2006). Accounting and Finance for Non-Specialists, $5^{\text {th }}$ Edition. London : Pearson Education Limited.

Brigham, E. F., \& Houston, J. F. (2009). Fundamentals of financial management, $12^{\text {th }}$ Edition. Mason : South-Western Cengage Learning.

Kieso, D. E., Weygandt, J. J., \& Warfield, T. D. (2013). Intermediate Accounting, $15^{\text {th }}$ Edition. New York : John Wiley \& Sons Inc.

Horngren, C. T., Datar, S. M., dan Rajan, M. V. (2012). Cost Accounting : A Managerial Emphasis, $14^{\text {th }}$ Edition. New Jersey : Pearson Education, Inc.

Horngren, C. T., Harrison Jr., W. T., \& Oliver, M. S. (2012). Accounting, $9^{\text {th }}$ Edition. New Jersey : Pearson Education, Inc.

Ikatan Akuntan Indonesia (IAI). 2015. Standar Akuntansi Keuangan.

Kimmel, P. D., Weygandt, J. J., dan Kieso, D. E. (2011). Accounting, $4^{\text {th }}$ Edition. New Jersey : John Wiley \& Sons, Inc.

Kinney, M. R., \& Raiborn, C. A. (2011). Cost Accounting: Foundations and Evolutions, $8^{\text {th }}$ Edition. Mason : South-Western, Cengage Learning.

Libby, R., Libby, P. A., \& Short, D. G. (2011). Financial Accounting, $7^{\text {th }}$ Edition. New York : McGraw-Hill Irwin

Nikolai, L., Bazley, J., \& Jones, J. (2010). Intermediate Accounting, $11^{\text {th }}$ Edition. Mason : South-Western, Cengage Learning

Warren, C. S., Reeve, J. M., dan Duchac, J. E. (2009). Accounting, $23^{\text {rd }}$ Edition. Mason : South Western Cengage Learning. 